Islamiconomic: Jurnal Ekonomi Islam

Volume 12 No. 1 January - June 2021

P-ISSN: 2085-3696; E-ISSN: 2541-4127

Page: 23 - 38

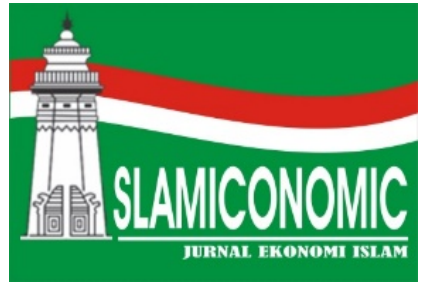

ISLAMICONOMIC: Jurnal Ekonomi Islam

Department of Islamic Economics

Faculty of Islamic Economics and Business

Universitas Islam Negeri Sultan Maulana Hasanuddin Banten

Jalan Jenderal Sudirman No. 30 Serang 42118

BANTEN - INDONESIA

Phone: +62254 200323 || Fax: +62254 200022 || Website: www. journal.islamiconomic.or.id

\title{
THE EFFECT OF HALAL AWARENESS AND FOOD INGREDIENTS ON CONSUMER INTERESTS OF CULINARY SEAFOOD BEACH TOURISM
}

\author{
Najmudin, ${ }^{{ }^{*}}$ Syihabudin, $^{2}$ Ahmad Fatoni ${ }^{3}$
}

123 Universitas Sultan Ageng Tirtayasa, Banten, Indonesia

*Corresponding author: najmudin@untirta.ac.id

Information
Article History:
Received : 18.05 .2021
Revised : 18.06 .2021
Accepted : 20.06 .2021

Keywords: Food Ingredients, Halal Awareness, Purchase Interest

\begin{abstract}
:
This study aims to determine (1). The effect of halal awareness on consumer buying interest in coastal tourism seafood culinary SMEs. (2). The influence of foodstuffs on consumer buying interest in coastal tourism seafood culinary SMEs. And (3). The influence of halal awareness and foodstuffs on consumer buying interest in coastal tourism seafood culinary SMEs. The object of this research is the culinary consumers of Seafood Kedaikita in Gope beach. The research method used is a quantitative method. The data collection method used a questionnaire. Data were analyzed using multiple linear regression method. The results of this study indicate that (1). Halal awareness affects the buying interest of consumers of beach tourism culinary SMEs. Shown by the value of $t$ is greater than table $(6,851>1.668)$ and the significance value is smaller than the alpha value $(0.000<0.05)(2)$. Foodstuffs affect consumer buying interest in coastal tourism culinary SMEs. Shown by the value of $t$ count greater than $t$ table $(5.784>1.668)$ and the significance value is smaller than the alpha value $(0.000<0.05)$. (3). Halal awareness and food ingredients have a positive and significant effect on the purchase interest of consumers of coastal tourism culinary SMEs. Shown by the value of $F$ count greater than $F$ table $(32,930>3.12)$ and the significance value is smaller than the alpha value $(0.000<0.05)$ 0.05). (3). Halal awareness and food ingredients have a positive and significant effect on the purchase interest of consumers of coastal tourism culinary SMEs. Shown by the value of $F$ count greater than $F$ table $(32,930>3.12)$ and the significance value is smaller than the alpha value $(0.000<0.05) 0.05)$. (3). Halal awareness and foodstuffs have a positive and significant effect on the purchase interest of consumers of coastal tourism culinary SMEs. Shown by the value of $F$ count greater than $F$ table $(32,930>3.12)$ and the significance value is smaller than the alpha value $(0.000<0.05)$.
\end{abstract}




\section{A. INTRODUCTION}

The 2020 ASEAN SME Transformation Study, United Overseas Bank (UOB) in collaboration with Accenture and Dun \& Bradstreet (D\&B) conducted a survey of 1,000 SMEs in five ASEAN countries. In details, Indonesia, Singapore, Malaysia, Thailand and Vietnam, to get an insight into the impact of the covid-19 pandemic. Based on the survey, around $52 \%$ of SME entrepreneurs stated that the drop in sales was the biggest concern during a pandemic. This condition was followed by pressure on cash flow, namely around 49\% of SMEs. (Nurhidayat, 2020).

In Indonesia Paper.id collaborated with SMESCO and OK OCE to conduct a survey entitled "The Impact of the COVID-19 Pandemic on MSMEs". This survey was conducted online and sent to more than 3000 MSMEs in 22 provinces of Indonesia. Based on existing data findings, as many as 78 percent of respondents admitted to experiencing a decrease in turnover. The largest category was in the decline of more than 20 percent (67.50 percent) and occurred in almost all business sectors. In the survey data, there are three types of businesses that experience the greatest impact, namely culinary (43.09 percent), services (26.02 percent), and fashion (13.01 percent). (Admin, 2020).

In line with that Ezizwita and Sukma (2021) stated that many culinary entrepreneurs in the world have been forced to temporarily close their businesses or even go bankrupt. Santia (2020) in Ezizwita and Sukma (2021) states that a startup digital cashier service provider for more than 30 thousand merchants in Indonesia, Moka, states that the food and beverage (F \& B) industry is the industry most affected by the corona virus. (Ezizwita \& Sukma, 2021).

Based on the data above, it is known that there has been a decrease in the amount of turnover in UKM culinary food and beverages during the pandemic period. This decline indicates a decrease in consumer buying interest in food and beverage culinary SMEs. Thus, this study tries to explore the effect of halal awareness and foodstuffs on the interest in buying beach tourism seafood culinary UKM, with the research locus of Gope Beach in Karangantu area, Serang City, Banten. 


\section{B. LITERATUR REVIEW}

\section{Halal Awareness}

Halal awareness is the level of understanding of Muslims in knowing problems related to the concept of halal. Such knowledge includes understanding what products can be consumed and how the production process is carried out(Environment \& Religion, 2017). The concept of halal according to Golnaz, et al (2010) in Anggraini and Dewanti (2020) emphasizes food safety, cleanliness and integrity. It also provides an excellent platform for healthy eating. Therefore, Muslims are aware that choosing halal products is very important not only to follow religious principles but to get food products that are in accordance with health standards. (Anggraini \& Dewanti, 2020). Aziz and Yuli (2013) in Puspita et al (2020) Consciousness is a concept that implies understanding and perception of an event or subject. Halal awareness from an industrial perspective is the awareness of consuming alcohol-free products and pork and their derivatives, but broader and more complex. Halal awareness is also the ability of a Muslim to understand what a halal product actually is. This includes awareness of how products are stored, sanitary practices, and transferred in the distribution system (Puspita et al., 2020). Meanwhile, according to Nurcahyo and Hudrasyah (2017) in Widyanto and Irfanur (2019) Halal awareness is the level of understanding for Muslims to be fully aware of the concept of halal and shape their decisions in buying and consuming halal products (Widyanto \& Irfanur, 2019). The indicators for measuring halal awareness according to Aziz \& Vui (2013) and Ahmad et al (2013) in Izzudin (2018) are (1) knowing the concept of halal, (2) knowing the halal process, (3) considering that consuming halal food is important for himself. (Izzudin, 2018).

\section{Food Ingredients}

Food ingredients according to Ardayanti et al (2013) in Laila and Tarmizi (2020) are everything that is contained in these foods. In Islamic thought, halal food is not just a matter of containing animal parts that are not halal for Muslims to eat or use. However, there are also certain criteria that must be considered such as halal food which also includes safety and quality aspects which are closely related to 
handling, processing, equipment, processing aids, packaging, storage, transportation, distribution and retail. (Lailla \& Tarmizi, 2020). Yunus et al. (2013) in Izzudin (2018) defines food ingredients as ingredients contained in a product that ensures whether the product is halal or not. Measurement of food composition variables refers to indicators, (1) The ingredients used in a product reflect halalness, (2) Foods with a clear halal composition, (3) information on food content. (Izzudin, 2018).

\section{Interests Buy}

Purchasing interest according to Schiffman \& Kanuk (2010) in Anggraini \& Dewanti (2020) is to choose one of two or more alternative choices to buy a product (Anggraini \& Dewanti, 2020). Assael (2001) in Nurcahyo \& Hudrasyah (2017) argues that purchase interest is the tendency of consumers to buy something or take purchase actions which can be measured by the consumer's desire to make a purchase. (Nurcahyo \& Hudrasyah, 2017). Kotler (2009) in Puspita A et al (2020) states that buying interest grows after consumers get a stimulus from the product they see, then a desire to try, until finally the desire to buy and own (Puspita et al., 2020). Indicators to measure purchase intention (1) decision to buy (2) recommend products to others (3) desire to buy (4) satisfaction. (Widyanto \& Irfanur, 2019).

The framework for this research can be seen in the following chart:

\section{Chart 1. Framework}

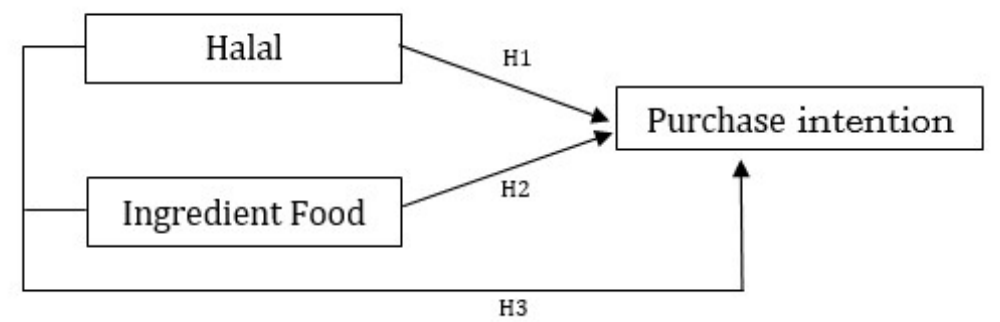

Source: Laila \& Tarmizi (2020)

\section{METHODOLOGY}

The method used in this research is quantitative method. According to Arikunto (2010) as quoted by Efendi (2018), quantitative research is research whose data is expressed in the form of numbers or numbers that can be calculated systematically 
Najmudin et.al.: The Effect of Halal Awareness...

(Efendi, 2018). The population according to Arikunto (1998) as quoted by Bachtiar (2018) is the entire research subject (Bachtiar, 2018). The population in this study were tourists who had bought and consumed seafood Kedaikita on Gope Beach, whose exact number was not known. The determination of the number of samples in this study refers to the opinion of Ferdinand (2002). Ferdinand (2002) as quoted by Izzudin (2018) states that the sample size depends on the number of indicators used in all variables. The number of samples is equal to the number of indicators multiplied by 5-10. Then the number of samples in this study was set at 80 respondents, which was obtained from the number of all indicator variables used in this study, namely 10 , then multiplied by $8(10 \times 8=80)$.

The type of data used in this research is primary data. According to Bungin (2015) as cited by Dewi and Sindarko (2018) primary data is data that is collected directly from the source and processed itself for use. The data collection method used was a questionnaire. The questionnaire according to Bungin (2015) as cited by Dewi and Sindarko (2018) is a questionnaire method or in the form of a series or collection of questions that are systematically arranged in a list of questions, then sent to respondents to be filled in (Dewi \& Sindarko, 2018). The questionnaire was distributed to 80 consumers of SMEs Culinary seafood Kedaikita in Gope Beach.

The data analysis method in this study is a quantitative descriptive approach, the analysis tool used is the SPSS version 23 program, the first test is the validity test used to measure whether a questionnaire is valid or not. Furthermore, the reliability test is where a questionnaire is said to be reliable or reliable if a person's answer to the statement is consistent or stable over time. After the instrument is valid and reliable, then multiple linear regression analysis is carried out, because there are two independent variables in this study. Hypothesis test which consists of $t$ test to partially see the effect of the independent variable on the dependent variable. Furthermore, the $\mathrm{F}$ test is to see the effect of the independent variable on the dependent variable simultaneously. (Ulya \& Karneli, 2018).

\section{RESULT AND ANALYSIS}

Gope Beach is located in the Karangantu area, Banten Village, Kasemen District, Serang City. This beach is called Gope, because tourists visiting the beach only need to 
pay 500 rupiah for two-wheeled vehicles and 1000 rupiah for four-wheeled vehicles. Gope beach tourism is like only other beach tourist location famous for its seafood food. One of the Seafood Culinary UKM in Gope Beach is Seafood Kedaikita. Seafood Kedaikita is well known by local, even national tourists, because Kedaikita seafood has been reviewed several times by Youtubers and its marketing has touched Facebook and Gofood media. The menu served at Kedaikita Seafood stalls can be seen in the following table:

Table 1. Menu and Prices for Seafood Kedaikita

\begin{tabular}{clc}
\hline No. & Menu & Price \\
\hline 1 & Green shells & $10 \mathrm{~K}$ \\
2 & Virgin Shells & $12 \mathrm{~K}$ \\
3 & Squid & $20 \mathrm{~K}$ \\
4 & Crab & $15 \mathrm{~K}$ \\
5 & Lobster & $22 \mathrm{~K}$ \\
6 & Ijo Dara & $10 \mathrm{~K}$ \\
7 & Ijo Dara Cumi & $15 \mathrm{~K}$ \\
8 & Ijo Dara Ceker & $25 \mathrm{~K}$ \\
9 & Ijo Dara Rajungan & $25 \mathrm{~K}$ \\
10 & Ijo Dara Lobster & $32 \mathrm{~K}$ \\
11 & Spill A: Green, Dara, Squid, Crab & $50 \mathrm{~K}$ \\
12 & Spill B: Green Shells, Dara, Lobster Squid & $62 \mathrm{~K}$ \\
13 & Spill C: Green Shells, Dara, Crab, Lobster & $62 \mathrm{~K}$ \\
14 & Spill D: Green clams, virgin, squid, lobster, crab & $77 \mathrm{~K}$ \\
\hline Source: Seafood Kedaikita. &
\end{tabular}

The validity test according to Ghozali (2011) in Faisal and Sari (2020) aims to measure whether a questionnaire is valid or not. An item is said to be valid if the statement on the questionnaire is able to reveal something that will be measured by the questionnaire (Faisal \& Sari, 2020). The validity test was carried out using the SPSS version 23 program, the test results can be seen in the following table:

Table 2. Validity Test Results

\begin{tabular}{cccc}
\hline Question Items & R Count Value & R Table Value & Conclusion \\
\hline Halal Awareness & & & \\
Variable & & & \\
X1.1 & 0.788 & 0.220 & Valid \\
X1.2 & 0868 & 0.220 & Valid \\
X1.3 & 0.904 & 0.220 & Valid \\
\hline
\end{tabular}


Najmudin et.al.: The Effect of Halal Awareness...

\begin{tabular}{cccc}
\hline $\begin{array}{l}\text { Variable Food } \\
\text { Ingredients }\end{array}$ & & & \\
X2.1 & 0.815 & 0.220 & Valid \\
X2.2 & 0.858 & 0.220 & Valid \\
X2.3 & 0814 & 0.220 & Valid \\
\hline $\begin{array}{c}\text { Purchase Interest } \\
\text { Variable }\end{array}$ & & \\
Y.1 & 0.680 & 0.220 & Valid \\
Y.2 & 0.728 & 0.220 & Valid \\
Y.3 & 0.822 & 0.220 & Valid \\
Y.4 & 0.808 & 0.220 & Valid \\
\hline
\end{tabular}

Source: SPSS data processed in 2021

Based on the results of the validity test in the table above, it is known that the rcount value of all question items is greater than $r$ table $(0.220)$, so it can be concluded that the question items in the questionnaire are all valid.

For reliability test, according to Ghozali (2011) in Faisal and Sari (2020) was conducted to test the consistency of respondents' statements from time to time. (Faisal \& Sari, 2020). The reliability test was carried out using the SPSS version 23 program. The results of the reliability test can be seen in the following table:

Table 3. Reliability Test Results

\begin{tabular}{lccc}
\hline Variable & $\begin{array}{c}\text { Cronbach's } \\
\text { Alpha value }\end{array}$ & $\begin{array}{c}\text { R Value } \\
\text { Table }\end{array}$ & Conclusion \\
\hline Halal Awareness (X1) & 0.815 & 0.220 & Reliable \\
Food Ingredients (X2) & 0.771 & 0.220 & Reliable \\
Purchase Interest (Y) & 0.757 & 0.220 & Reliable \\
\hline Source: SPSS data processed in 2021 & &
\end{tabular}

Based on the reliability test results on the table above, it is known that the cronbach's alpha value of the halal awareness variable (X1) is greater than the rtable $(0.815>0.220)$, the cronbach's alpha value of the foodstuff variable (X2) is greater than the rtable $(0.771>0.220)$ and the value cronbach's alpha purchase interest variable $(Y)$ is greater than rtable $(0.757>0.220)$. Thus it can be concluded that all variables in this study are reliable and reliable.

The normality test aims to test whether the residuals in the regression model follow the normal distribution or not. The normality test was carried out using the 
Islamiconomic: Jurnal Ekonomi Islam

Vol.12 No.1 January - June 2021

SPSS v program. 23. The results of the normality test can be seen in the following table:

Table 4. Kolmogorov Smirnov Normality Test Results One-Sample Kolmogorov-Smirnov Test

\begin{tabular}{|c|c|c|}
\hline & & $\begin{array}{c}\text { Unstandardiz } \\
\text { ed Residual }\end{array}$ \\
\hline$\overline{\mathrm{N}}$ & & 80 \\
\hline \multirow[t]{2}{*}{ Normal Parametersa, b } & Mean & .0000000 \\
\hline & $\begin{array}{l}\text { Std. } \\
\text { Deviation }\end{array}$ & 1.73259796 \\
\hline Most Extreme & Absolute & .074 \\
\hline Differences & $\begin{array}{l}\text { Positive } \\
\text { Negative }\end{array}$ & $\begin{array}{r}.054 \\
-.074\end{array}$ \\
\hline Statistical Test & & .074 \\
\hline Asymp. Sig. (2-tailed) & & $.200 \mathrm{c}, \mathrm{d}$ \\
\hline $\begin{array}{l}\text { a. Test distribution is No } \\
\text { b. Calculated from data. } \\
\text { c. Lilliefors Significance } \\
\text { d. This is a lower bound }\end{array}$ & $\begin{array}{l}\text { Iormal. } \\
\text { Correctior } \\
\text { d of the tru }\end{array}$ & ificance. \\
\hline
\end{tabular}

Source: SPSS data processed in 2021

Based on the results of the normality test in the table above, it is known that the significance value of the Kolmogorov Smirnov test is greater than the alpha value $(0.200>0.05)$, so it can be said that the model data residuals are normally distributed or the normality assumption has been met.

The multicollinearity test according to Ghozali (2011) in Ayuwardani and Isroah (2018) aims to test whether the regression model finds a correlation between one independent variable and another. The regression model can be said to be good if there is no correlation between the independent variables by looking at the VIF value and the Tolerance value of each independent variable, if the tolerance value $>0.10$ and the VIF value $<10$, it can be concluded that the data is free from multicollinearity symptoms. (Ayuwardani \& Isroah, 2018). The multicollinearity test was carried out using the SPSS v program. 23, the multicollinearity test results can be seen in the following table:

Table 5. Multicollinearity Test Results

\section{Coefficientsa}

Unstandardized Standardized

Model Coefficients Coefficients $t$ Sig. Collinearity Statistics


Najmudin et.al.: The Effect of Halal Awareness...

\begin{tabular}{llrrrrrrr}
\hline \hline & \multicolumn{1}{c}{ B } & Std. Error & \multicolumn{1}{l}{ Beta } & & Tolerance & VIF \\
\hline 1 & (Constant) & 3,769 & 1,569 & & 2,402 & .019 & & \\
& Halal Awareness & .405 & .085 & .456 & 4,794 & .000 & .775 & 1,290 \\
& Food material & .462 & .132 & .332 & 3,492 & .001 & .775 & 1,290 \\
a. Dependent Variable: Purchase Interest & & & & &
\end{tabular}

Source: SPSS data processed in 2021

The table above shows that the halal awareness variable and foodstuff variables each have a tolerance value greater than $0.10(0.775>0.10)$ and a VIF value less than $10(1,290<10)$, it can be concluded that the data is free of multicollinearity symptoms.

Heteroscedasticity test aims to test whether in the regression model there is an inequality of variance from the residuals of one observation to another. If the variance from one observation to another is constant, it is called homoscedasticity and if it is different it is called heteroscedasticity. (Chairina Kusumaningrum, 2015). Heteroscedasticity test in this study using the Glejser test. The test was carried out using the SPSS v. 23, the test results can be seen in the following table:

Table 6. Heteroscedasticity Test Results

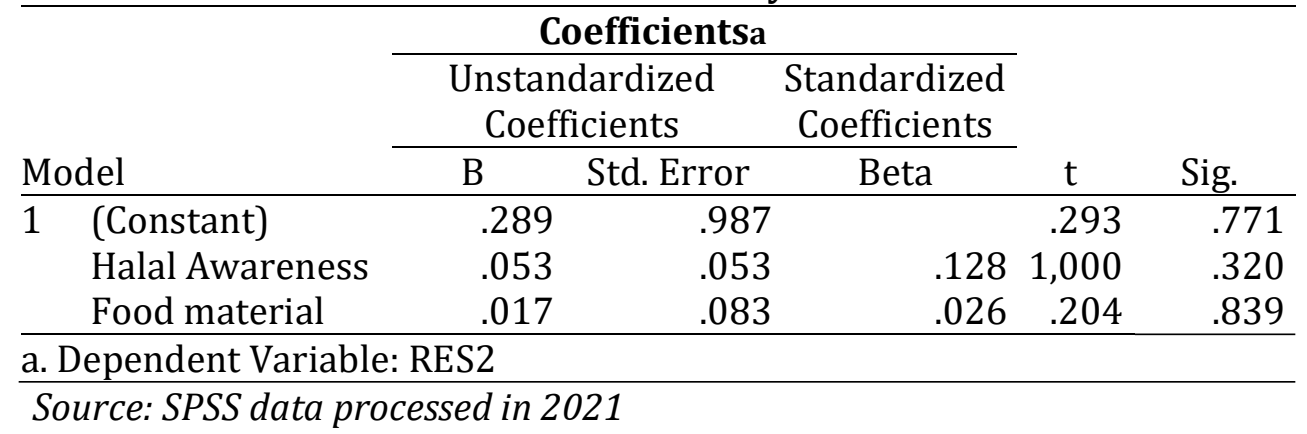

The table above shows that the significance value of the halal awareness variable is greater than the alpha value $(0.320>0.05)$ and the food ingredient variable significance value is greater than the alpha value $(0.839>0.05)$, so it can be concluded that there is no heteroscedasticity in the regression model in this study.

The coefficient of determination test aims to determine the percentage contribution of the influence of the halal awareness variable (X1), foodstuffs (X2) on purchase intention (Y). The coefficient of determination (R2) from the multiple regression results shows how much the dependent variable is influenced by the 
Islamiconomic: Jurnal Ekonomi Islam Vol.12 No.1 January - June 2021

independent variable. The correlation coefficient test was carried out using the SPSS v program. 23, The test results of the coefficient of determination (R2) can be seen in the following table:

Table 7. Correlation Coefficient Test Results

\begin{tabular}{|c|c|c|c|c|}
\hline \multicolumn{5}{|c|}{ Model Summary } \\
\hline Model & $\mathrm{R}$ & R Square & $\begin{array}{l}\text { Adjusted R } \\
\text { Square }\end{array}$ & $\begin{array}{l}\text { Std. Error of } \\
\text { the Estimate }\end{array}$ \\
\hline$\overline{1}$ & $.679 a$ & .461 & .447 & 1.75495 \\
\hline
\end{tabular}

a. Predictors: (Constant), Food Ingredients, Halal

Consciousness

Source: SPSS data processed in 2021

The test results table above shows that the value of the correlation coefficient of the variable of halal awareness and foodstuffs on the buying interest of consumers of the Seafood Culinary SMEs in Gope beach is 0.447 This value indicates that the purchase interest of consumers of Gope beach Seafood Culinary SMEs is influenced by awareness of halal and foodstuffs as much as 44.7 percent, while the remaining 55.3 is influenced by other variables not examined in this study.

The statistical F test aims to test the hypothesis of the simultaneous effect of the independent variable (X) on the dependent variable (Y). In this research hypothesis, it is assumed that the halal awareness variable (X1) and foodstuffs (X2) jointly affect purchase intention (Y). The independent variable forming the regression model is said to have a significant effect simultaneously if Fcount $>$ Ftable or significant $<\alpha=$ 0.05, the statistical F test was carried out using the SPSS v program. 23, the test results can be seen in the following table:

Table 8. F Statistical Test Results

\begin{tabular}{llrrrrr}
\hline \multicolumn{7}{c}{ ANOVAa } \\
\hline \multicolumn{1}{c}{ Model } & Sum of & & & & \\
\hline 1 & Regression & Squares & df & Mean Square & F & Sig. \\
\hline & Residual & 202,838 & 2 & 101,419 & 32,930 & $.000 \mathrm{~b}$ \\
& Total & 437,150 & 77 & 3,080 & & \\
\hline
\end{tabular}

a. Dependent Variable: Purchase Interest

b. Predictors: (Constant), Food Ingredients, Halal Consciousness Source: SPSS data processed in 2021

Based on the results of the statistical $\mathrm{F}$ test above, it is known that the F value of the variable of halal awareness and foodstuffs is 32,930 and the significance value is 32 
Najmudin et.al.: The Effect of Halal Awareness...

0,000 . while the $\mathrm{F}$ table value is 3.14 and an alpha value is 0.05 . When compared according to the formula above, the value of $\mathrm{F}$ count is greater than $\mathrm{F}$ table $(32,930>$ $3.12)$ and the significance value is smaller than the alpha value $(0.000<0.05)$. Thus, halal awareness and foodstuffs simultaneously influence the buying interest of consumers of coastal tourism seafood culinary SMEs.

Partial regression model testing is used to determine whether each independent variable forming the regression model individually has a significant effect on performance or not. To test for the partial effect, the t test was used, namely by comparing the value of $t$ count with $t$ table. The independent variable forming the regression model is said to have a significant effect if tcount $>$ ttable or significant $<\alpha=$ 0.05. The partial regression model testing is as follows:

\section{Table 4.9. Statistical t-test results}

\begin{tabular}{|c|c|c|c|c|c|c|}
\hline \multicolumn{7}{|c|}{ Coefficientsa } \\
\hline \multirow[b]{2}{*}{ Model } & & \multicolumn{2}{|c|}{$\begin{array}{l}\text { Unstandardized } \\
\text { Coefficients }\end{array}$} & \multirow{2}{*}{$\begin{array}{c}\begin{array}{c}\text { Standardized } \\
\text { Coefficients }\end{array} \\
\text { Beta }\end{array}$} & \multirow[b]{2}{*}{$\mathrm{t}$} & \multirow[b]{2}{*}{ Sig. } \\
\hline & & $\mathrm{B}$ & Std. Error & & & \\
\hline$\overline{1}$ & (Constant) & 7,400 & 1,257 & & 5,889 & .000 \\
\hline & Halal Awareness & .545 & .080 & .613 & 6,851 & .000 \\
\hline
\end{tabular}

a. Dependent Variable: Purchase Interest

Source: SPSS data processed in 2021

Based on the results of the statistical t test in the table above, it is known that the $t$ value of the halal awareness variable is 6,851 and the significance value is 0,000 , while the $t$ value of the halal awareness variable is 1,668 and the alpha value is 0.05 . When compared, the $t$ value is greater than the $t$ table $(6,851>1,668)$ and the significance value is smaller than the alpha value $(0.000<0.05)$. Thus, halal awareness has a significant effect on the interest in buying seafood from SMEs culinary beach tourism.

Table 4.10. Statistical T-test results

\begin{tabular}{|c|c|c|c|c|c|c|}
\hline \multicolumn{7}{|c|}{ Coefficientsa } \\
\hline \multirow[b]{2}{*}{ Model } & & \multicolumn{2}{|c|}{$\begin{array}{c}\text { Unstandardized } \\
\text { Coefficients }\end{array}$} & \multirow{2}{*}{$\begin{array}{c}\begin{array}{c}\text { Standardized } \\
\text { Coefficients }\end{array} \\
\text { Beta }\end{array}$} & \multirow[b]{2}{*}{$\mathrm{t}$} & \multirow[b]{2}{*}{ Sig. } \\
\hline & & $\mathrm{B}$ & Std. Error & & & \\
\hline \multirow[t]{2}{*}{1} & (Constant) & 6,295 & 1,673 & & 3,762 & .000 \\
\hline & Food material & .762 & .132 & .548 & 5,784 & .000 \\
\hline
\end{tabular}

a. Dependent Variable: Purchase Interest

Source: SPSS data processed in 2021 
Based on the results of the $t$ statistical test, it is known that the $t$ statistical value ( $t$ count) of the foodstuff variable is 5.784 and the significance value is 0.000 , while the $t$ value of the foodstuff variable is 1.668 and the alpha value is 0.05 . When compared, the $t$ value is greater than the $t$ table $(5.784>1.668)$ and the significance value is smaller than the alpha value $(0.000<0.05)$. Thus, foodstuffs have a positive and significant effect on the interest in buying seafood UKM beach tourism culinary.

\section{Discussion}

\section{The Effect of Halal Awareness on Purchase Intention}

Based on the results of the above research, the results of the $t$ statistic $x 1$ against y show that the t-count value of the halal awareness variable is greater than the $t$ table $(6,851>1,668)$ and the significance value is smaller than the alpha value $(0.000<0.05)$. Thus, halal awareness has a positive and significant effect on the purchase interest of consumers of UKM culinary seafood, Gope beach tourism. This shows that the better the consumer's halal awareness, the more their buying interest in UKM culinary seafood culinary beach tourism. The halal awareness referred to here is (1) know the concept of halal, (2) know the processing of halal food, (3) consider that consuming halal food is important for him.

The results of this study are in line with research conducted by Anggaraini and Dewanti (2020), the results of their research show that halal awareness has a positive effect on the buying interest of Muslim communities living in Indonesia. (Anggraini \& Dewanti, 2020). Nurhasanah et al. (2018), the results of his research show that halal awareness has a positive and significant effect on the purchase intention of halal processed food products for consumers (Nurhasah et al., 2018). Nofianti and Rofiqoh (2019), the results of their research show that halal awareness has a positive effect on consumer buying interest (Nofianti \& Rofiqoh, 2019). Setyaningsih and Marwansyah (2019), the results of their research show that halal awareness has a positive effect on buying interest in halal food products. (Setyaningsih \& Marwansyah, 2019). Izzudin (2018), the results of his research show that halal awareness has a positive effect on buying interest in Garahan Pecel Rice(Izzudin, 2018). Lailla and Tarmizi (2020), the results of their research show that halal 
Najmudin et.al.: The Effect of Halal Awareness...

awareness has a positive and significant effect on the interest in buying halal food in food court, Muhammadiyah University, Jakarta. (Lailla \& Tarmizi, 2020).

\section{The Effect of Food Ingredients on Purchase Intention}

Based on the results of the above research, the results of the t statistical $x 2$ on $y$ test show that the $t$ statistical value ( $\mathrm{t}$ count) of the foodstuff variable is 5.784 and the significance value is 0.000 , while the t table value of the foodstuff variable is 1.668 and the alpha value is 0.05 . When compared, the $t$ value is greater than the table (5.784> 1.668) and the significance value is smaller than the alpha value 0.000 $<0.05$ ). This indicates that foodstuffs have a positive and significant effect on the buying interest of consumers of SME Culinary Seafood on beach tourism. Thus, the better and more halal the seafood ingredients are, the more consumers will buy them. The food ingredients referred to here are (1) The ingredients used in seafood reflect halalness.

The results of this study are in line with the research conducted by Izzudin (2020), the results of his research show that food ingredients have a significant positive effect on buying interest in culinary foods. (Izzudin, 2018). The results of Hayani's research (2019) show that food ingredients have a significant positive effect on buying interest in food products (Hayani, 2019). And the research results of Lailla and Tarmizi (2020) which show that food ingredients have a significant positive effect on buying interest in UMJ Courd food. (Lailla \& Tarmizi, 2020).

\section{The Effect of Halal Awareness and Food Ingredients on Purchase Intention}

Based on the results of the above research, the results of the F statistical test $\mathrm{x} 1$ and $\mathrm{x} 2$ on $\mathrm{y}$ note that the F-count value of the halal awareness variable and foodstuffs is 32,930 and the significance value is 0,000 . while the $F$ table value is 3.14 and an alpha value is 0.05 . When compared, then the value of $\mathrm{F}$ count is greater than $\mathrm{F}$ table $(32,930>3.12)$ and the significance value is smaller than the alpha value 0.000 $<0.05$ ). These results indicate that halal awareness and foodstuffs simultaneously influence the buying interest of consumers of coastal seafood culinary SMEs. The contribution of the influence of halal awareness and foodstuffs on the purchase interest of consumers of UKM culinary seafood in Gope Beach tourism was $44.7 \%$, the 
Islamiconomic: Jurnal Ekonomi Islam Vol.12 No.1 January - June 2021

remaining $55.3 \%$ was influenced by other variables not examined in this study. Thus, the better the consumer's halal awareness and the better and halal the food ingredients used in processing seafood, the more consumers' buying interest in seafood food will increase. The results of this study are in accordance with the results of research by Lailla and Tarmizi (2020) which show that awareness of halal and food ingredients has a significant positive effect on the interest in buying food Courd UMJ food.(Lailla \& Tarmizi, 2020).

\section{E. CONCLUSION}

Based on the results of the research and discussion above, it can be concluded that halal awareness has a positive and significant effect on the buying interest of consumers of coastal tourism seafood culinary SMEs, food ingredients have a positive and significant effect on the buying interest of consumers of Seafood Culinary SMEs on beach tourism, awareness of halal and food ingredients. Simultaneously influence the purchase interest of consumers of coastal seafood culinary SMEs with an influence contribution $44.7 \%$, the remaining $55.3 \%$ is influenced by other variables not examined in this study.

\section{F. REFERENCES}

Admin. (2020). Usaha Kuliner Paling Kena Dampak Pandemi Covid-19. Kabarkampus.Com. https://kabarkampus.com/2020/11/usaha-kuliner-palingkena-dampak-pandemi-covid-19/

Anggraini, I., \& Dewanti, D. S. (2020). The Effect of Halal Foods Awareness on Purchase Decision with Religiosity as a Moderating Variable. Journal of $\begin{array}{llll}\text { Economics Research Social } & \text { Sciences, }\end{array}$ https://doi.org/10.18196/jerss.040116

Ayuwardani, R. P., \& Isroah, I. (2018). Pengaruh Informasi Keuangan dan Non Keuangan Terhadap Underpricing Harga Saham Pada Perusahaan yang Melakukan Initial Publiv Offering (Studi Empiris Perusahaan Go Public yang terdaftar di Bursa Efek Indonesia Tahun 2011-2015). Nominal, Barometer Riset Akuntansi Dan Manajemen, 7(1). https://doi.org/10.21831/nominal.v7i1.19781 Bachtiar, D. I. (2018). Analisis Pengaruh Diversifikasi Produk dan Harga terhadap 
Najmudin et.al.: The Effect of Halal Awareness...

Keputusan Pembelian pada UKM Gula Kelapa. Jurnal Ekonomi Dan Bisnis, 52-60.

Chairina Kusumaningrum, F. R. (2015). Pengaruh Labelisasi Halal dan Promosi Terhadap Keputusan Pembelian Produk Makanan Dalam Kemasan (Studi Kasus di Masyarakat Kecamatan Lowokwaru Kota Malang). Jurnal Ilmiah Mahasiswa FEB Universitas Brawijaya, 3(2), 1161-1163.

Dewi, L., \& Sindarko, W. (2018). Pengaruh Keragaman Dan Kualitas Produk Terhadap Keputusan Pembelian Konsumen La Cherie. Jurnal Ilmu Manajemen Dan Akuntansi Terapan (JIMAT), 9(2), 61-69.

Dilingkungan, S., \& Agama, P. (2017). Ijtihad hakim dalam menyelesaikan sengketa ekonomi syariah dilingkungan peradilan agama. IJTIHAD HAKIM DALAM MENYELESAIKAN SENGKETA EKONOMI SYARIAH DILINGKUNGAN PERADILAN AGAMA Ruslaini, 8(November 2017), 150-170.

Efendi, W. D. (2018). Pengaruh Variasi Produk, Kemasan dan Iklan terhadap Keputusan Pembelian Ice Cream Campina di Mini Market Wilayah Kota Kediri. Jurnal SIMKI - Ekonomic Universitas Nusantara PGRI Kediri, 2(2), 1-12.

Ezizwita, E., \& Sukma, T. (2021). Dampak Pandemi Covid-19 Terhadap Bisnis Kuliner Dan Strategi Beradaptasi di Era New Normal. Jurnal Ekonomi Dan Bisnis Dharma Andalas, 23(1), 51-63. https://doi.org/10.47233/jebd.v23i1.169

Faisal, Y., \& Sari, E. G. (2020). Pengaruh Kemudahan Informasi Dan Kualitas Informasi Terhadap Keputusan Bersedekah Di Masjid - Masjid Kota Batam. Jesya (Jurnal Ekonomi \& Ekonomi Syariah), 3(2), 70-80. https://doi.org/10.36778/jesya.v3i2.191

Hayani, N. (2019). Pengaruh Sertifikasi Halal Dan Bahan Makanan Terhadap Keputusan Pembelian Produk Makanan Oleh Ibu Rumahtangga Muslim Di Pekanbaru. Al-Amwal, 8(1), 31-44.

Izzudin, A. (2018). Pengaruh Label Halal, Kesadaran Halal Dan Bahan Makanan Terhadap Minat Beli Makanan Kuliner. Penelitian Ipteks, 3(2), 100-114. http://jurnal.unmuhjember.ac.id/index.php/PENELITIAN_IPTEKS/article/view /1886/1547

Lailla, N., \& Tarmizi, I. (2020). Pengaruh Kesadaran Halal dan Bahan Makanan Terhadap Minat Beli Makanan di Food Courd UMJ. Prosiding Konferensi Nasional $\begin{array}{lllll}\text { Ekonomi Manajemen Dan Akuntansi } & \text { (KNEMA), }\end{array}$ 
https://jurnal.umj.ac.id/index.php/KNEMA/

Nofianti, K. A., \& Rofiqoh, S. N. I. (2019). Kesadaran Halal dan Logo Halal: Apakah Menentukan Minat Beli? (Studi Pada Pelaku Bisnis UMKM di Gresik). Journal of Halal Product and Research, 2(1), 16-24. https://doi.org/10.20473/jhpr.vol.2issue.2.51-59

Nurcahyo, A., \& Hudrasyah, H. (2017). The Influence of Halal Awareness, Halal Certification, and Personal Societal Purchase Intention. Journal of Business and Management, 6(1), 21-31.

Nurhasah, S., Munandar, J. M., \& Syamsun, M. (2018). Faktor-Faktor yang Mempengaruhi Minat Beli Produk Makanan Olahan Halal pada Konsumen. Jurnal Manajemen Dan Organisasi, 8(3), 250-260. https://doi.org/10.29244/jmo.v8i3.22473

Nurhidayat, D. (2020). Atasi Dampak Pandemi, Banyak UKM Andalkan Penjualan Daring. Mediaindonesia.Com. https://mediaindonesia.com/ekonomi/357948/atasi-dampak-pandemibanyak-ukm-andalkan-penjualan-daring

Puspita, W. A., Sunaryo, \& Wijayanti, R. (2020). The Effects between Religious Belief, Halal Logo, and Halal Product Knowledge on Purchase Intention Mediated by Halal Awareness (Study on Consumers Of Beverage Franchise Products In Malang). South East Asia Journal of Contemporary Business, Economics and Law, 21(5), 306-319.

Setyaningsih, E. D., \& Marwansyah, S. (2019). The Effect of Halal Certification and Halal Awareness through Interest in Decisions on Buying Halal Food Products. Syi ar Iqtishadi: Journal of Islamic Economics, Finance and Banking, 3(1), 65. https://doi.org/10.35448/jiec.v3i1.5515

Ulya, A. N., \& Karneli, O. (2018). Pengaruh Diversifikasi dan Kualitas Produk terhadap Kepuasan Pelanggan pada Toko Rabbani Cabang Pekanbar. JOM FISIP, 5(Edisi II Juli - Desember), 1-14.

Widyanto, H. A., \& Irfanur, M. K. (2019). Faith-Based Marketing: Antecedents of Purchase Intention for Halal-Certified Personal Care Products. Jurnal Muara Ilmu Ekonomi Dan Bisnis, 3(2), 421. https://doi.org/10.24912/jmieb.v3i2.7338 